\title{
Discrimination: The Plight of the Travelling Community
}

\author{
Brian Kenna \\ Portlaoise Prison
}

There is no group in Irish society that has experienced the level of systematic discrimination, harassment, and inhuman treatment that the travelling community has. Media coverage, particularly the print media, has consistently portrayed travellers in a negative light, often associating them with crime and violence seldom recognising the discrimination, poverty, and prejudice which is their daily experience. Travellers are very often refused service in shops, pubs, and places of entertainment. It is not uncommon to see travellers physically ejected from these places or from houses, buildings, parks, or indeed, streets. Having been refused service in pubs, travellers are invariably arrested for drinking in the streets, charged with vagrancy, usually convicted, and more often than not, jailed.

The Irish travelling community comprises a small but highly stigmatised minority group. The name for their treatment by the rest of Irish society is racism. This racism is perpetrated on this minority group despite the fact that our society has been both unable and unwilling to provide the travelling community with even the most basic housing, adequately serviced halting sites, health services, or educational opportunities. All of us have, at one time or another, experienced, been witness to, or been the perpetrators of this racism. Those of us who have not actively practised this racism, have from time to time turned a blind eye or given the deaf ear to such instances. We have looked the other way in shops, pubs, hotels, etc, as travellers were shown the door, and we have pretended not to hear as they have been verbally humiliated and treated as less than human by officials in housing, welfare, and health departments. By choosing to ignore the racism in our midst, we deny the travelling community the right to be treated as equal citizens. By turning our backs on this atrocious situation we are guilty of racism through indifference. Our reluctance to face down the racism we see around us is cowardly. Our continued silence on the issue is a shameful disgrace.

We can all, no doubt, recall examples of the treatment meted out to travellers in our own communities. A couple of years ago, a number of travellers on the Avilla Park site, a permanent halting site in the Finglas area of Dublin, decided to enter a travellers' soccer team in the Dublin Amateur League. They approached a local pub, The Cardiff Inn, seeking sponsorship for their jerseys. The owner obliged them with a full rig out amounting to a couple of hundred pounds, and in return, he asked that the jerseys advertise the name of the pub. All went well and Avilla United played and won their first match. After the game they retired to The Cardiff Inn for a celebratory drink but the owner 
refused them service on the grounds that he had a 'No Travellers' policy. It would be funny ... but it is not.

Around the same time, another Avilla Park resident, Martin Collins, was the recipient of Ireland's Young Person of the Year award for his educational work with young travellers. On the night of his award, he went to The Drake Inn in Finglas and was greeted with the 'No Travellers' policy. He could be presented with an award from the President but was not apparently presentable enough to be served in his local pub.

Witness the dole payments from the men's labour exchange in Dublin's Gardiner St. Everyone signing on is classified alphabetically: A-F sign on Mondays, G-M sign on Tuesdays, and so on. They are all given set times to turn up so there will not be over crowding at any given time. It's like that all week Monday, Tuesday, Wednesday, Friday. I left out Thursday. Well, Thursday is different. Thursday at 11:00 a.m., all the travellers assigned to that dole office, regardless of alphabetical order, are brought in together. Herded in, paid out, and herded out again. You may decide for yourself why this might be so, but lest you think (as the common assumption goes) that it's done to prevent them 'doing the double' or signing on in more than one dole office, then think again. There are many, if not more, settled people involved in this activity as there are travellers. And when you think about it, this type of fraud says more about the derisory nature of dole payments than anybody's dishonesty. It's humiliating enough to have to put your hand out to feed yourself or your family, but to do it twice deserves a medal. Besides, whatever revenue may be pinched from the government through this type of activity is but a drop in the ocean compared to the business and finance scandals going on in this country, day in and day out. If as much effort and energy were put into detecting irregularities by those at the upper level of the social scale, and if these people, once detected, were dealt with by the due course of law, they would have to build new jails to accommodate them all.

A few weeks ago, we had a visit from Neil Peterson, the singlehanded yachtsman, who came in to tell us of his experiences as a coloured South African and particularly of his time spent in this country after being shipwrecked in the Atlantic. He spoke of the generosity of the Irish people, how they provided the materials to repair his boat and the money to finance the continuation of his journey. During the discussion which followed his talk, Peterson was asked whether he had encountered any racism since he had been in Ireland. Sure he had, but he was not the victim. Rather, he was shocked to see how Irish society treated the travelling community. A familiar tale really. The Irish, champions of the underdog, the dispossessed, the poverty stricken, victims of famine, oppressed minorities. Dedicated, committed, tireless campaigners on behalf of all these causes, any cause really, as long as it's not in this country.

If any of us were to take just a moment or two to reflect upon our own experiences of how, as Republicans, we have been the victims of political 
isolation and attempted ostracisation because of the stand we have been prepared to make, we get some small notion of how society treats the travelling community. But bear in mind that, as republicans, we make a conscious decision to go the road we choose, in some cases giving up a lifestyle, which, while not necessarily always comfortable, is nonetheless cosy to the extent that we have limited access to housing, education, health care, and (although now rapidly disappearing) employment opportunities. Should our commitment to the Republican Movement falter or lessen in any way and we decide that this road is too long or too difficult for us, we can at any time decide we have had enough and go back to our 'cosy' lives. While of course the vast majority of republican activists would not choose the easy option, it is precisely the fact that we could make this choice that ensures we will see this campaign to its conclusion. Travellers have no such choices. Born into an ethnic minority they quickly become aware of the dehumanising limits of second-class citizenship.

Despite the well-to-do appearance of some, most travellers exist without the comforts of electricity, running water, refuse collection, or sanitation. They have high birth rates, low life expectancy, and a high level of illiteracy. Since the early 1960s, the Irish government and many voluntary organisations have sought to eliminate what they regarded as the 'problem' of itinerancy by settling travellers and assimilating them into mainstream society. 'Recently, however, travellers have begun to demand the right to maintain their nomadic lifestyle and ethnic identit.' (Gmelch, Ireland From Below).

The Irish travelling community is just one of many itinerant minorities of traders, artists, and entertainers who live in complex societies around the world but particularly in Europe. Whilst the traveller population in Ireland is somewhere in the region of 25,000 , they have a worldwide collective strength as travellers/gypsies closer to ten million. According to Sharon Gmelch, who has carried out extensive research on the travelling community, 'travellers form a large biologically self-perpetuating group that share fundamental cultural values and have an overt unity of cultural form (that is, they share certain externally observable behavioural and material traits). Moreover, travellers interact primarily with each other, interaction with the settled community being largely limited to economic dealings and formal institutional settings such as the courts and hospitals.'

The travelling community, then, is constantly aclearly-defined ethnic group. Twenty-five thousand people is perhaps a relatively small minority, even in Irish terms, but statistics show that the travelling community has doubled in size in the last 20 years, and due to a continuing high birth rate (the average family consists of twelve), this trend is likely to continue.

\section{BACKGROUND}

Traditionally, Irish travellers lived in tents and horse-drawn wagons. Up until the $1960 \mathrm{~s}$ in fact, $90 \%$ of travellers still lived in this fashion. They generally 
earned their living going from house to house peddling tin and copperware, sweeping chimneys, picking crops, and doing odd jobs on farms. Most travellers would base themselves within one or two counties. One exception to this would have been the horse dealers who rounded up horses and Connemara ponies in the West and brought them to fairs or to Dublin's Smithfield Market to be sold. In early winter, they might settle into rented cottages or abandoned houses and take to the roads again in spring. Travellers formed single communities on the basis of shared lifestyles and family relationships. One of the most disruptive features of evictions of travellers today is that it often forces them to live in groups or on settlements not of their own choosing. Family clans can be split as only limited space becomes available on some sites while some families are forced to live in large settlement camps with families they may not get on with.

The migration of travellers from rural to urban areas began in the $1960 \mathrm{~s}$. The introduction of plastic and enamelware containers following the Second World War gradually eliminated the need for the itinerant 'tinker.' Likewise, road improvements and the increased ownership of cars gave rural people greater access to shops, etc., thus reducing their dependency on the rural peddler and itinerant tradesman. Mechanisation on the farm did away with the need for large numbers of farm labourers and there was a decreasing need for the traction animals sold by the travellers. As a result of this, travellers moved from rural areas to cities to look for work. In 1950, there were fewer than 10 traveller families living in Dublin. By 1973, it had risen to 310 families. In 1981, it was 580 , now it's 1200 . Travellers today generally live in urban areas. They make a living by collecting scrap metal, dealing in used car parts, and selling household goods from door to door. Whatever income they manage is supplemented by state welfare benefits.

The migration of travellers to urban areas in the late 1950s/early 1960 s and the pitching of tents and wagons in city areas alarmed urban dwellers who complained about the potential health hazards from the camps, the danger of wandering horses, and the nuisance of being repeatedly asked for water and handouts. Opposition to travellers was often strongest among the workingclass residents of the new housing estates built in the city suburbs. The reason for this was that these people had been generally transferred from inner-city tenements and they saw their improved standards and expectations of upward mobility threatened by the siting of large and unsightly traveller camps beside them.

By 1966, the report of the Commission on Itinerancy was published and this focused national attention on what had by then become known as Ireland's 'itinerant problem.' The report drew attention for the first time to the problems of poverty, illiteracy, ill health, and the high mortality rates among travellers, and this in turn aroused a measure of public sympathy for their plight. Itinerant Settlement Committees were set up with the aim of improving the living standards of travelling families by building serviced campsites with 'tigins' 
(small houses), running water, toilets, and electricity. The ultimate goal was to absorb travellers into the settled community. Today, about $50 \%$ of the travelling population in Ireland has been settled, either into chalet type houses on official traveller campsites or into conventional housing. However, the other half of the travelling community is still nomadic, living in caravans or trailers on the roadside or official halting sites. Ironically, due to population growth, there are more travellers living on the roadside today than before the settlement movement began.

In recent years, we have seen the growth of the Traveller Rights Movement. Apart from the frustration and hardship created by frequent evictions, many urban travellers feel a growing sense of deprivation. Living in close proximity to the comparatively well off urban dwellers, the travellers have become disillusioned. The living conditions for most travellers are still far from good. Evictions not only disrupt economic activities, they also scatter social relationships, disrupt medical care, and discontinue children's education. Eviction policies and continuing public harassment have given the travellers a strong impetus to organise themselves. In 1982 the Committee for the Rights of Travellers was formed, and although initially it was run by traveller and nontraveller people, by 1984 a new organisation had been formed, 'Minceir Misli' (Travellers Movement). This traveller-run organisation calls for traveller rights and organises protest marches and demonstrations. Today, they are a very efficient organisation with their own regular newspaper. Much of their energy is put into securing full legal rights for travellers, a campaign to end discrimination and negative stereotypes, and to help traveller/non-traveller relations. They seek consultation in any government development programme aimed at the travellers and they campaign for more housing as well as more camping sites for those travellers who wish to remain nomadic.

The most complete statement of traveller goals is articulated in the draft Charter of Traveller Rights. It contains twelve articles (e.g. housing, free expression, the vote, state welfare, education, and health) covering their rights as a minority group as well as specific rights to travel and to accommodation that is compatible with a nomadic lifestyle. The Charter also calls for recognition of their distinct identity and the right to maintain this identity through their traditional way of life.

How we, in the settled community treat the travellers says everything about our society. There is no such thing as limited equality. We cannot deny one sector of society equal rights and then demand civil, legal, political, and human rights for ourselves. The travelling community is different from other sections of Irish society. They have their own ethnic cultural background but they form part of the rich diversity of Irish culture. If we are to seriously address the problems of social inequality in our society, perhaps the rights of the travellers would be a good place to start. 